\title{
Exploring the world of micro sculptures - subfossil Cladocera remains under the SEM
}

\author{
Izabela Zawiska, ${ }^{1 *}$ Edyta Zawisza, ${ }^{2}$ Marta Wojewódka, ${ }^{2}$ Artem Y. Sinev ${ }^{3}$ \\ ${ }^{1}$ Department of Geoecology and Climatology, Institute of Geography and Spatial Organization, Polish Academy of Sciences, Twarda \\ 51/55, PL-00-818 Warsaw, Poland; ${ }^{2}$ Institute of Geological Sciences, Polish Academy of Sciences, Twarda 51/55, PL-00-818 Warsaw, \\ Poland; ${ }^{3}$ Department of Invertebrate Zoology, Biological Faculty, Lomonosov Moscow State University, Leninskie Gory, 119991 \\ Moscow, Russia \\ *Corresponding author: izawiska@twarda.pan.pl
}

\begin{abstract}
The scanning electron microscope (SEM) is widely used for the identification of microstructural characteristics and morphology of different microorganisms. Common procedures are based and developed for remains of living species. This paper presents an effective method for drying and preparing subfossil Cladocera remains for SEM observation, which has been recently adapted and tested on several samples originating from different American and European lakes. This method results to be fast and cheap, as it excludes the use of expensive and toxic reagents. Moreover, it allows to recognize the micro sculpture and other species specific characteristics present on the different body parts of the Cladocera remains. The present contribution provides 29 high quality pictures of 12 cladoceran species at magnification between 200x and 11,000x. SEM images reveal that the patterns observed on the shells under the light microscope actually are always three dimensional structures.
\end{abstract}

Key words: SEM; subfossil Cladocera; micro sculpture; chitin.

Received: August 2016. Accepted: December 2016.

\section{INTRODUCTION}

Analysis of subfossil Cladocera (Crustacea: Branchiopoda) is widely used in paleolimnology given its potential to reconstruct past environmental conditions (Korhola and Rautio, 2001; Nevalainen and Rautio, 2014; Zawiska et al., 2015). Cladocerans are used as indicators of several abiotic and biotic environmental variables (Rumes et al., 2011; Chen et al., 2014), as they are very sensitive to changes in total phosphorus concentrations (Amsinck et al., 2005; Chen et al., 2010), water depth (Korhola et al., 2005; Nevalainen et al., 2011; Gałka et al., 2014), temperature (Lotter et al., 1997; Korhola, 1999; Mirosław-Grabowska and Zawisza, 2013; Nevalainen et al., 2013; Zawiska et al., 2015), pH (Locke and Sprules, 2000; Zawiska et al., 2013).

The crucial step in subfossil Cladocera analysis is the correct taxonomical identification of the remaisns at the species level, which is usually based on the use of light microscope (magnification 100-400x) and several determination keys ( Alonso, 1996; Szeroczyńska and SarmajaKorjonen, 2007; Korosi and Smol, 2012). As the light microscopy allows to observe the remains in two dimensions, the body sculpture appears to be only a pattern on the surface of the carapace. The microstructural characteristics of the chitinous remains can be observed in three- dimensional appearance only by scanning electron microscope (SEM), which enables to create images by scanning the surface with a focused beam of electrons (Goldstein et al., 2003). The magnifications obtained with SEM are much greater than those of light microscopy and reach 100,000x.

SEM is commonly used in taxonomy of living Cladocera to describe morphological features such as the limb setae, the lateral pores or the shell denticles (Sinev et al., 2005; Sinev and Elmoor-Loureiro, 2010). Cladocera for SEM observations are usually collected from water by using a plankton net and dried using either a wide range of alcohol percentages $(70 \%, 90 \%, 95 \%, 100 \%)$ (Duigan, 1992; Nandini et al., 2009), or the strong reagent hexamethyldisilazane (Laforsch and Tollrian, 2000; Sousa et al., 2015; Juračka et al., 2016). Saha et al. (2011) recently presented a new simplified procedure, where specimens collected from water samples are washed in distilled water, dried in the room temperature for 30 mins, coated with gold palladium and examined with SEM.

SEM images are also frequently used in paleolimnology to study sediment properties, such as the origin of carbonates (terrestrial or autogenic), porosity, composition of lamination and microfossil taxa identification (Kemp et al., 2001; Martín-Serrano et al., 2009; Wetzel, 2013; Kirillova et al., 2016). They are also very useful in observing small morphological details of microorganism and 
often help to identify remains such as diatoms (Battarbee, 2001) or testate amoebae (Beyens and Meisterfeld, 2001). Therefore, the methodology for preparing the subfossil remains of these organism for SEM observation is well established (Jiang et al., 2015). On the contrary, Cladocera subfossil remains are still rarely observed under the SEM (Kirillova et al., 2016). In fact, although Cladocera skeleton is composed of fairly hard chitin, the typical thickness variation depending on the species, body part and lake environment conditions, make the Cladocera preparation for SEM more complicated and time-consuming (AndradeMorraye et al., 2004). The sediment samples should be firstly prepared according to standard procedure (Frey, 1986), then remains have to be picked up from the samples and washed several time with distilled water. After that remains should be put to osmium tetroxide for $2 \mathrm{~h}$, washed in distilled water again and submitted to the ethanol dehydration sequence (Andrade-Morraye et al., 2004). When the remains are acquired from unconsolidated sediments they have to be submitted to dehydration in graded alcohols solutions (Kirillova et al., 2016).

In our research we aimed at testing whether the simplified method proposed by Saha et al. (2011) for aquatic samples could be applied also to subfossil Cladocera remains in order to obtain good quality pictures.

\section{METHODS}

Subfossil Cladocera remains for SEM observation were obtained from sediment samples using two approaches. In the first one fresh sediment from different lakes located in Central and South America was analysed (i.e. from Lake Comendador, Lake Chicabal, Lake Quexil (Guatemala), Lake Emiliano Zapata (Yucatan Peninsula, Mexico), Lake Los Negritos, Lake Verde (Salvador), Lake Madre Vieja, (Honduras), Lake San Martin, (Argentina). Remains were picked directly from the unconsolidated upper first $\mathrm{cm}$ of surface sediments $\left(1 \mathrm{~cm}^{3}\right)$, diluted with distilled water and put into a petri dish. Cladocera remains were pick out using a pipette (in the drop of water) under the dissecting microscope and directly put on the SEM microscope stubs covered with a carbon adhesive tape.

In the second approach the sediment samples for SEM observation were obtained from European Lakes, i.e. Atnsjøen (Norway), Czechowskie (Poland) and Suchar IV (Poland). Samples were taken from sediment cores and chemically prepared for subfossil Cladocera analysis according to standard procedures (Szeroczyńska and Sarmaja-Korjonen, 2007). The amount $1 \mathrm{~cm}^{3}$ of fresh sediment was treated with hot $10 \% \mathrm{KOH}$ for 20 min using a magnetic stirrer in order to deflocculate the material and remove humic substances. Thereafter the carbonates were removed using $10 \% \mathrm{HCl}$. The remaining material was sieved through $33 \mu \mathrm{m}$ mesh and diluted in $10 \mathrm{~cm}^{3}$ distilled water. The subfossil remains were removed consecutively with a pipette from the cleaned sediment and directly put on the SEM microscope stubs covered with a carbon adhesive tape.

The remains obtained from both superficial fresh sediments and cleaned core material were left to dry at the room temperature for $48 \mathrm{hs}$. When dried they were put into the sputter coater SC7620 for $120 \mathrm{~s}$ and coated with a gold-palladium. The sample coating with an electric conducting material is necessary in order to avoid the accumulation of electrostatic charge at the sample surface (Sinev et al., 2005; Sinev and Elmoor-Loureiro, 2010). After the specimens were coated they were put into the scanning electron microscope (Jeol JSM-6610LV) chamber and observed in high vacuum, using SEI mode, voltage $20 \mathrm{kV}$.

\section{RESULTS}

Figures 1-8 show 29 good quality images of subfossil Cladocera remains belonging to 12 Cladocera species. The pictures were taken at magnification ranging from 200x to 11,000x. The remains from both fresh sediments and from the sediment cores have different state of preservation, independently from the age of the sample. The remains of Chydorus spp. (Leach) preserved well and therefore easier to be photographed, compared to the other observed Cladocera species (Figs. 1 and 2). The SEM pictures allowed to observe magnificent sculpture of Ceriodaphnia spp. (Dana) and Simpocephallus ephippia (Schoedler) (Figs. 3 and 4). The delicate structure of Alonella excisa (Fischer) shell and Leydigiopsis ornata (Daday) (Fig. 5), the deep carvings of Graptoleberis testudinaria (Fischer) and Monospilus dispar (Sars) (Fig. 6), as well as characteristic triangle on the Paralona pigra (Sars) shell are well documented (Fig. 1). The SEM pictures revealed the three-dimensional aspect of the head pores of Alona ossiani (Sinev), Bosmina (E.) coregoni (Baird) and Bosmina (E.) longispina (Leydig) (Fig. 7). On the contrary, the specimens form lake Suchar IV showed high level of degradation, and diminished sculpture of the remains (Fig. 8). This might be possibly due to the fact that these sediment samples were prepared for subfossil Cladocera analysis already five years ago.

\section{DISCUSSION}

The simplified procedure of preparing specimens for SEM observation proposed by Saha et al. (2011) was tested on different remains of Cladocera species from several American and European lakes. This procedure is based on the concept developed for the remains of living species (Sinev et al., 2005; Van Damme and Dumont, 

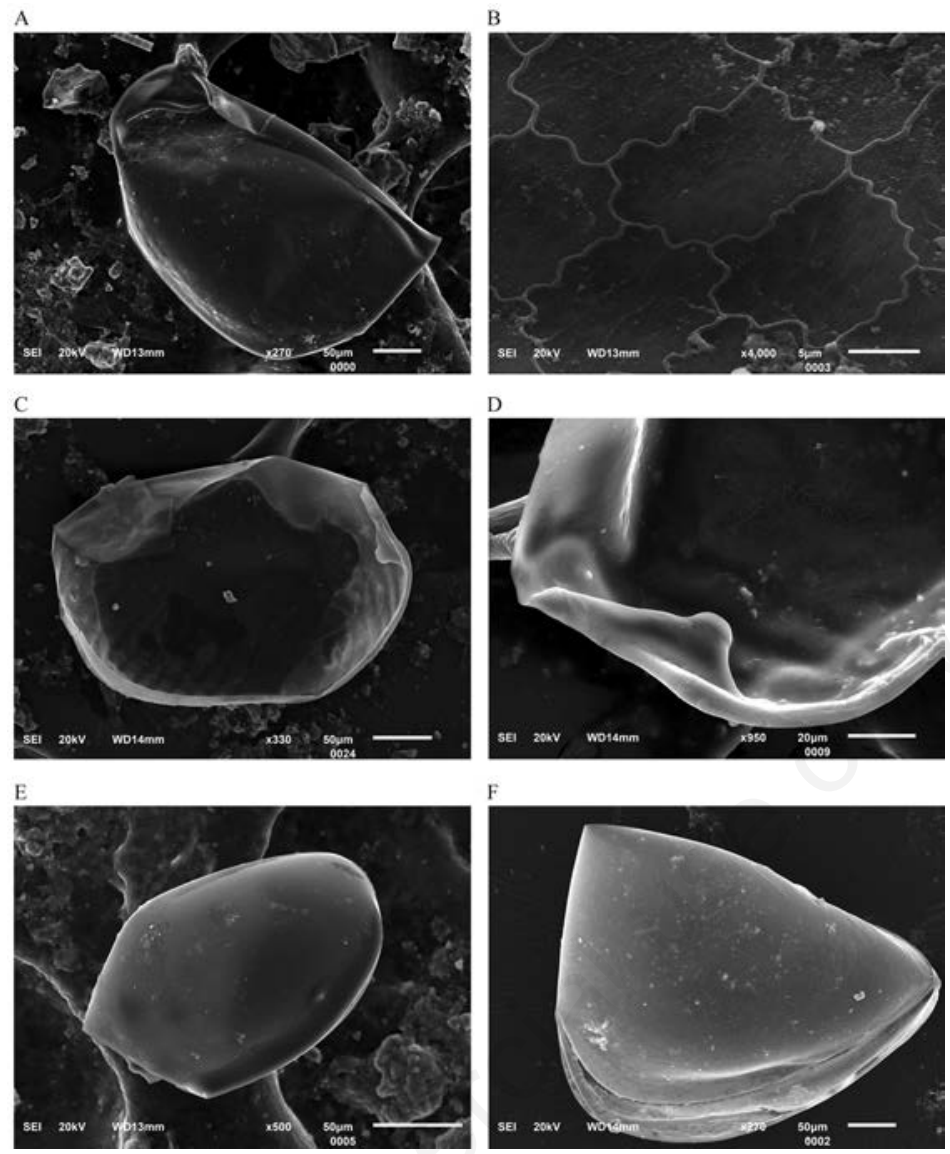

Fig. 1. SEM images of Cladocera remains. A) Chydorus sphericus shell, magnification 270x (Lake Comendador, Guatemala). B) Chydorus sphericus shell sculpture, magnification 4000x (Lake Comendador, Guatemala). C) Paralona pigra shell, magnification 330x (Lake San Martin, Argentina). D) Paralona pigra shell, triangular anterior accessory flange on the anteriror-ventral margin, magnification 950x (Lake San Martin, Argentina). E) Chydorus spp., magnification 500x (Lake Comendador, Guatemala). F) Chydorus spp., magnification 270x (Lake Comendador, Guatemala).
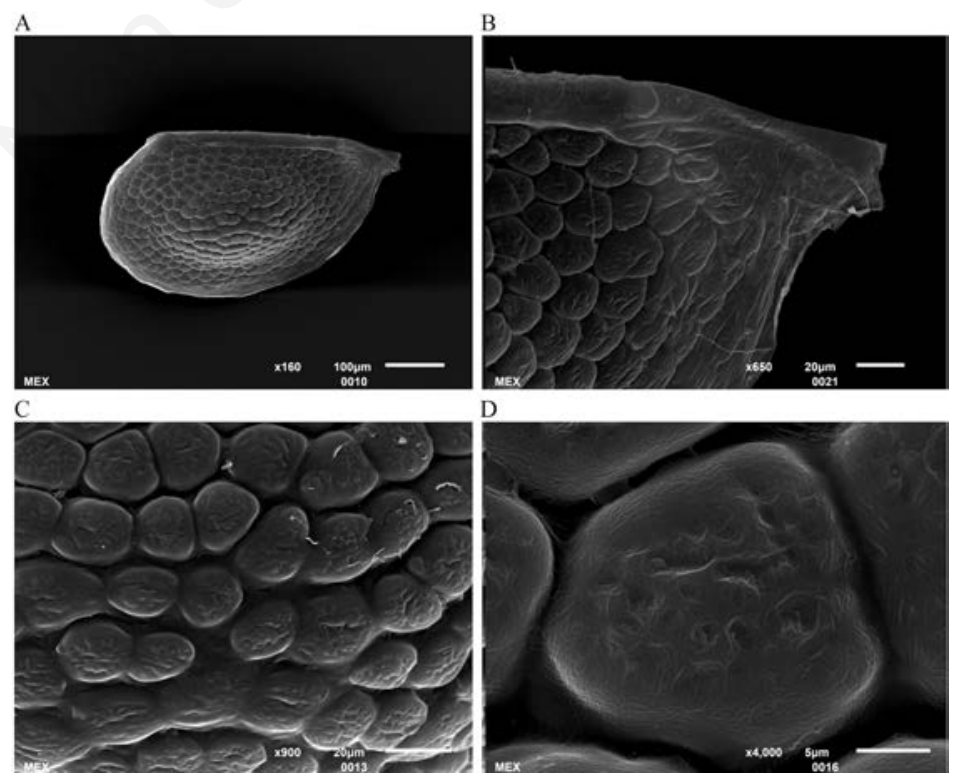

Fig. 2. SEM images of Cladocera remains of Ceriodaphnia spp. ephippium (Lake Emiliano Zapata, Yucatan Peninsula, Mexico). Magnification: A) 160x; B) 650x; C) 900x; D) 4000x. 
2007; Sinev and Elmoor-Loureiro, 2010; Kotov, 2013; Sousa et al., 2015). The time for drying the remains suggested by Saha et al. (2011) was not long enough in the case of fragmented parts of the cladoceran body found in the studied samples. Since most of them were very small and difficult to pick out from the sediment sample with a needle, they were put on the stage with a pipette, in a fairly large drop of water. Therefore the prolongation of the drying time was necessary.

From all types of examined Cladocera remains, ephippia showed the best reservation of structure and ornamentation, as their chitinous envelope is thick and less prone for mechanic destruction. It was also noted that not all subfossil Cladocera remains were suitable for SEM observation, as some were so thin that the specimens were barely visible. In addition, it was recognized that the subfossil material for SEM observation should be pick out from the freshly prepared sediment sample, as the remains slowly degrade and the chitin structure become less prominent after sediment preparation (Fig. 8). The SEM images clearly showed that the patterns on the shells observed under the light microscope always correspond to three dimensional structures.

\section{CONCLUSIONS}

The simplified method of preparing subfossil Cladocera was applied on different samples from several lakes. The presented method resulted to be simple, cheap and allowed to create high quality images of all types of re-
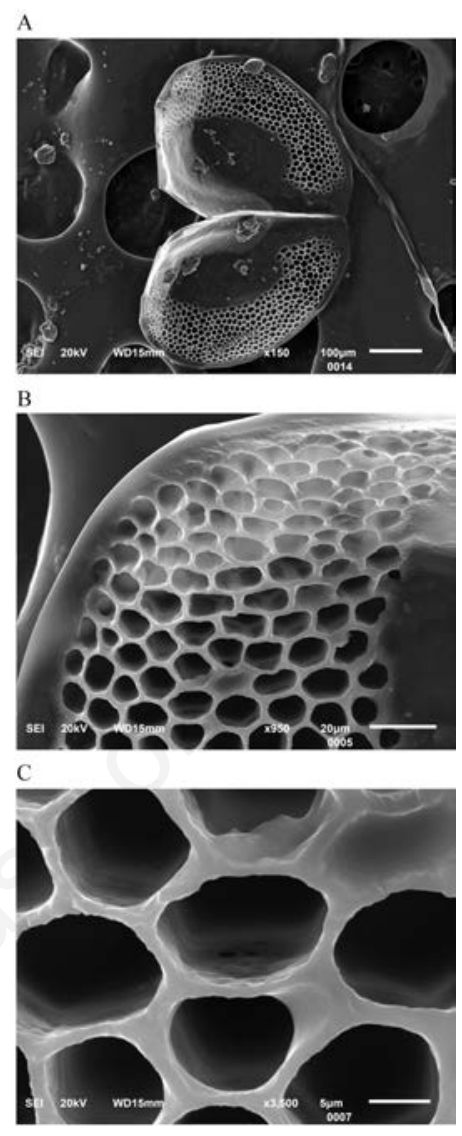

Fig. 3. SEM images of Cladocera remains of Simpocephalus spp. ephippium (Lake Chicabal, Guatemala). Magnification: A) 150x; B) 950x; C) 3500x.
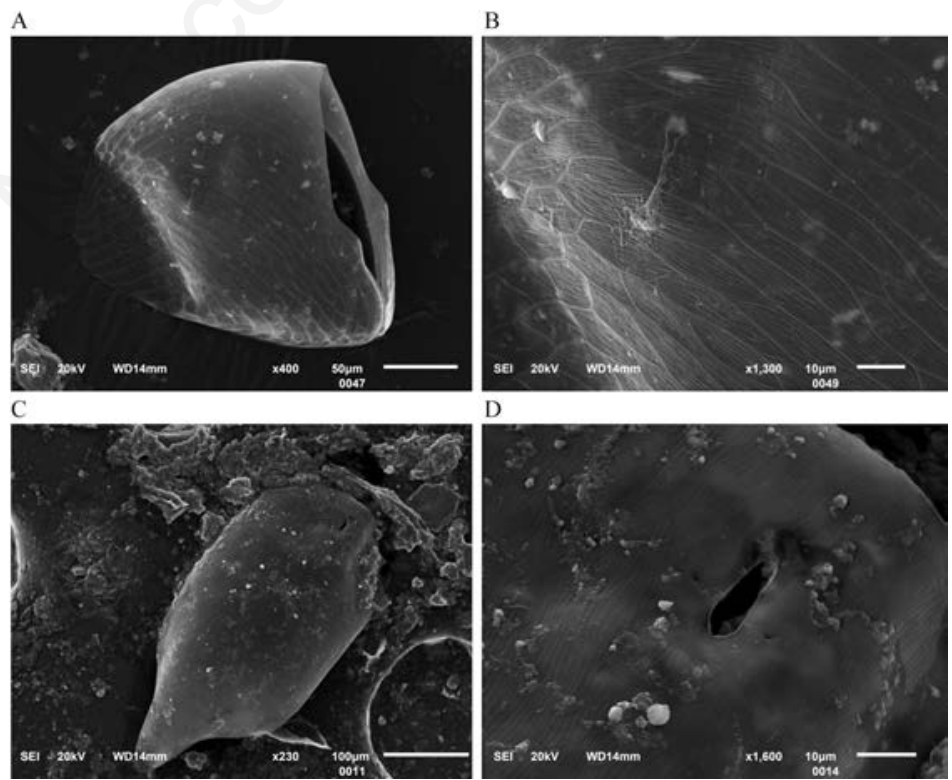

Fig. 4. SEM images of Cladocera remains. A) Alonella excisa shell, magnification 400x (Lake Quexil, Guatemala). B) Alonella excisa shell sculpture, magnification 1300x (Lake Quexil, Guatemala). C) Leidigiopsis ornata head, magnification 230x (Lake Los Negritos, Salvador). D) Leidigiopsis ornata head sculpture, magnification 1600x (Lake Los Negritos, Salvador). 

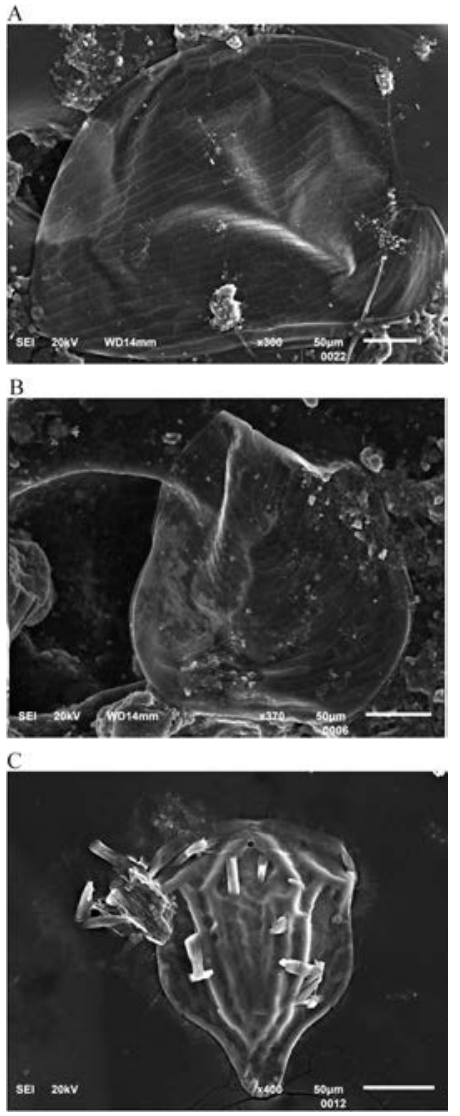

Fig. 5. SEM images of Cladocera remains. A) Graptoleberis testudinaria shell, magnification 300x (Lake Verde, Salvador). B) Graptoleberis testudinaria head, magnification 370x (Lake Verde, Salvador). C) Monospilus dispar head, magnification 400x (Czechowskie Lake, Poland).
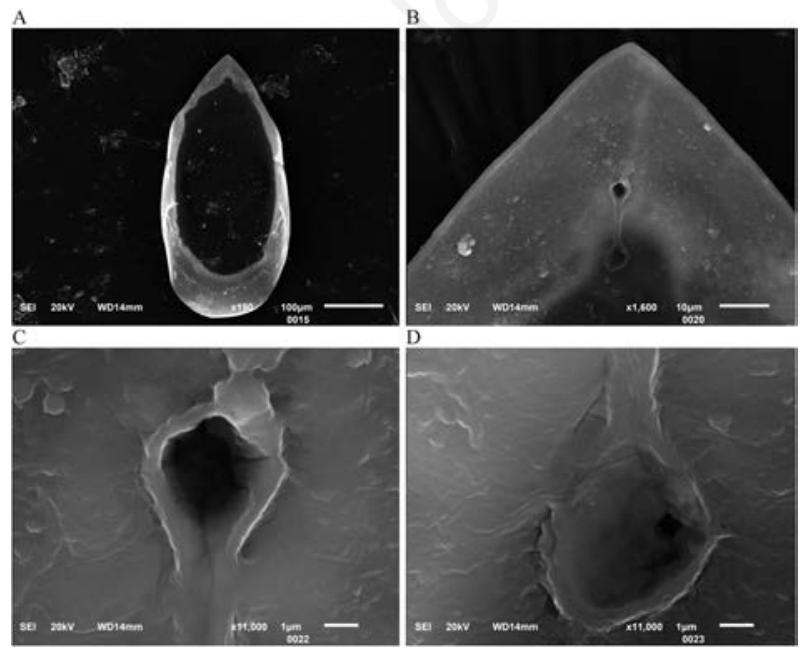

Fig. 6. SEM images of Cladocera remains of Alona ossiani head (Lake Madre Vieja, Honduras). Magnification: A) 190x; B) 1600x; C,D) 11,000x. mains even in fairly high magnifications up to $11,000 \mathrm{x}$. Although the procedure developed for the remains of living species revealed to be effective also for subfossil Cladocera, it appeared necessary to prolong the drying time when working with subfossil remains. Moreover, the samples should be prepared just before the SEM analysis, in order to prevent the degradation of the micro sculpture after the cleaning procedure.
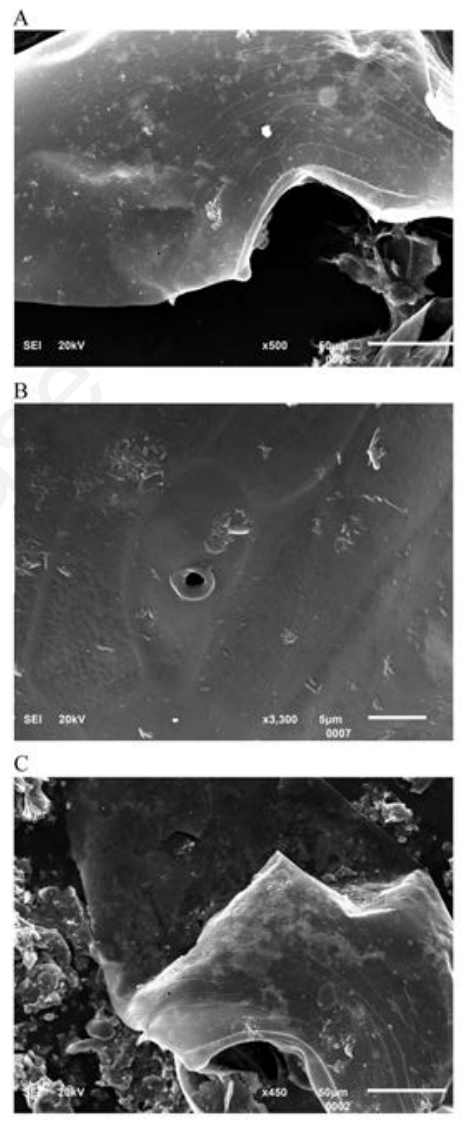

Fig. 7. SEM images of Cladocera remains from Lake Atnsjøen, Norway. A) Bosmina E.coregoni head, magnification 500x. B) Bosmina E.coregoni head pore, magnification 3300x. C) Bosmina E. longispina head, magnification $800 \mathrm{x}$.

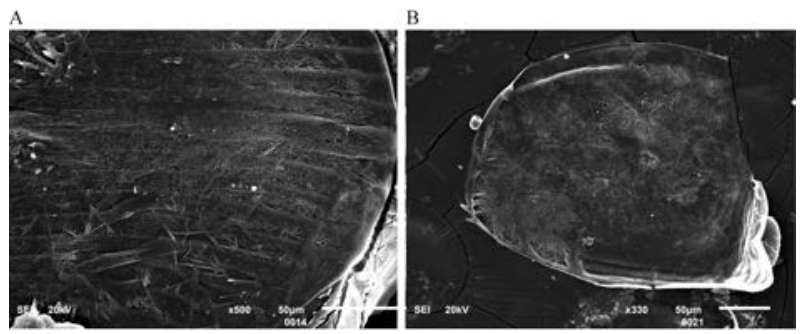

Fig. 8. SEM images of Cladocera decaying remains from sediment from Lake Suchar IV (Poland) prepared for subfossil Cladocera analysis 4 years ago. Magnification: A) 500x; B) $330 \mathrm{x}$. 


\section{ACKNOWLEDGMENTS}

The research was founded by Polish National Science Centre, grant NCN 2014/13/B/ST10/02534 and by the EEA and Norway Grants (Grant no. 459 FSS/2013/IIC/W/0022). The presented work was made possible thanks to the support of Institute of Geography and Spatial Organization and Institute of Geological Sciences, Polish Academy of Sciences.

\section{REFERENCES}

Alonso M, 1996. [Crustacea, Branchiopoda].[in Spanish]. Museo Nacional de Ciencias Naturales, Consejo Superior de Investigaciones Cientificas, Madrid, Spain.

Amsinck SL, Jeppesen E, Landkildehus F, 2005. Relationships between environmental variables and zooplankton subfossils in the surface sediments of 36 shallow coastal brackish lakes with special emphasis on the role of fish. J. Paleolimnol. 33:39-51.

Andrade-Morraye M, Eskinazi-Sant'Anna EM, Rocha O, 2004. A method for preparing remains of Cladocera (Crustacea) and Chironomid (Diptera: Insecta) for scanning electron microscopy. Braz. J. Biol. 64:911-912.

Battarbee RW, 2001. Diatoms. In: J.P. Smol, B. Birks John and W.M. Last (eds.), Tracking environmental change using lake sediments. 3. Terrestrial, Algal, and Siliceous Indicators. Kluwer Academic Publishers, Dodrecht.

Beyens L, Meisterfeld R, 2001. Protozoa. Testate Amoebae. In: J.P. Smol, B. Birks John and W.M. Last (eds.), Tracking environmental change using lake sediments. 3. Terrestrial, Algal, and Siliceous Indicators. Kluwer Academic Publishers, Dodrecht.

Chen G, Dalton C, Taylor D, 2010. Cladocera as indicators of trophic state in Irish lakes. J. Paleolimnol. 44:465-481.

Chen WY, Tao S, Adams JM, Jacques FMB, Ferguson DK, Zhou Z-K, 2014. Large-scale dataset from China gives new insights into leaf margin-temperature relationships. Palaeogeogr. Palaeoclimatol. Palaeoecol. 402:73-80.

Duigan CA, 1992. The ecology and distribution of the littoral freshwater Chydoridae (Branchiopoda, Anomopoda) of Ireland, with taxonomic comments on some species. Hydrobiologia 241:1-70.

Frey DG, 1986. Cladocera analysis, p. 667-692. In: B.E. Berglund (ed.), Handbook of Holocene palaeoecology and palaeohydrology. John Wiley \& Sons, Chichester.

Gałka M, Tobolski K, Zawisza E, Goslar T, 2014. Postglacial history of vegetation, human activity and lake-level changes at Jezioro Linówek in northeast Poland, based on multiproxy data. Veg. Hist. Archaeobot. 23:123-152.

Goldstein J, Newbury DE, Joy DC, Lyman CE, Echlin P, Lifshin E, Sawyer L, Michael JR, 2003. Introduction, p. 1-20. In: J. Goldstein, D.E. Newbury, D.C. Joy, C.E. Lyman, P. Echlin, E. Lifshin, L. Sawyer, J.R Michael (eds.), Scanning Electron Microscopy and X-ray Microanalysis. 3rd ed. Springer, Boston.

Jiang W, Pan H, Wang F, Jiang M, Deng X, Li J, 2015. A rapid sample processing method to observe diatoms via scanning electron microscopy. J. Appl. Phycol. 27:243-248.
Juračka PJ, Sacherová V, Dobiášovská I, Bovšková D, Novosadová Z, Kořínek V, Petrusek A, 2016. Simplification of preparation techniques for scanning electron microscopy of Cladocera: preparing filtering limbs and ephippia for efficient studies of ultrastructure. Crustaceana 89:47-62.

Kemp AES, Dean J, Pearce RB, Pike J, 2001. Recognition and analysis of beddingand sediment fabric features, p. 7-22. in: W.M. Last and J.P. Smol (eds.), Tracking environmental change using lake sediments: physical and geochemical methods. Springer, Dordrecht.

Kirillova IV, Van Der Plicht J, Gubin SV, Kotov AA, 2016. Taphonomic phenomenon of ancient hair from Glacial Beringia: perspectives for palaeoecological reconstructions. Boreas 45:455-469.

Korhola A, 1999. Distribution patterns of Cladocera in subarctic Fennoscandian lakes and their potential in environmental reconstruction. Ecography 22:357-373.

Korhola A, Rautio M, 2001. Cladocera and other branchiopod crustaceans, p. 5-41. in: W.M. Last and J.P. Smol (eds.), Tracking environmental change using lake sediments. 4. Zoological Indicators. Springer, Dordrecht.

Korhola A, Tikkanen M, Weckström J, 2005. Quantification of Holocene lake-level changes in Finnish Lapland using a cladocera - lake depth transfer model. Journal of Paleolimnology 34:175-190.

Korosi JB, Smol JP, 2012. An illustrated guide to the identification of cladoceran subfossils from lake sediments in northeastern North America: part 1 - the Daphniidae, Leptodoridae, Bosminidae, Polyphemidae, Holopedidae, Sididae, and Macrothricidae. J. Paleolimnol. 48:571-586.

Kotov AA, 2013. Morphology and phylogeny of the Anomopoda (Crustacea: Cladocera). KMK Scientific Publishers, Moscow: 638 pp.

Laforsch C, Tollrian R, 2000. A new preparation technique of daphnids for Scanning Electron Microscopy using hexamethyldisilazane. Arch. Hydrobiol. 149:587-596.

Locke A, Sprules WG, 2000. Effects of acidic pH and phytoplankton on survival and condition of Bosmina longirostris and Daphnia pulex. Hydrobiologia 437:187-196.

Lotter A, Birks HJ, Hofmann W, Marchetto A, 1997. Modern diatom, cladocera, chironomid, and chrysophyte cyst assemblages as quantitative indicators for the reconstruction of past environmental conditions in the Alps. I. Climate. J. Paleolimnol 18: 395-420.

Martín-Serrano A, García-Cortés A, Galán L, Gallardo-Millán JL, Martín-Alfageme S, Rubio FM, Ibarra PI, Granda A, PérezGonzález A, García-Lobón JL, 2009. Morphotectonic setting of maar lakes in the Campo de Calatrava Volcanic Field (Central Spain, SW Europe). Sediment. Geol. 222:52-63.

Mirosław-Grabowska J, Zawisza E, 2013. Late Glacial-early Holocene environmental changes in Charzykowskie Lake (northern Poland) based on oxygen and carbon isotopes and Cladocera data. Quatern. Int. 328-329:156-166.

Nandini S, Silva-Briano M, García García G, Sarma SSS, Adabache-Ortiz A, Galván de la Rosa R, 2009. First record of the temperate species Daphnia curvirostris Eylmann, 1887 emend. Johnson, 1952 (Cladocera: Daphniidae) in Mexico and its demographic characteristics in relation to algal food density. Limnology 10:87-94.

Nevalainen L, Luoto TP, Kultti S, Sarmaja-Korjonen K, 2013. 
Spatio-temporal distribution of sedimentary Cladocera (Crustacea: Branchiopoda) in relation to climate. J. Biogeogr. 40:1548-1559.

Nevalainen L, Rautio M, 2014. Spectral absorbance of benthic cladoceran carapaces as a new method for inferring past UV exposure of aquatic biota. Quaternary Sci. Rev. 84:109-115.

Nevalainen L, Sarmaja-Korjonen K, Luoto TP, 2011. Sedimentary Cladocera as indicators of past water-level changes in shallow northern lakes. Quaternary Res. 75:430-437.

Rumes B, Eggermont H, Verschuren D, 2011. Distribution and faunal richness of Cladocera in western Uganda crater lakes. Hydrobiologia 676:39-56.

Sinev AY, Elmoor-Loureiro LM, 2010. Three new species of chydorid cladocerans of subfamily Aloninae (Branchipoda: Anomopoda: Chydoridae) from Brazil. Zootaxa 2390:1-25.

Sinev AY, Van Damme K, Kotov A, 2005. Redescription of tropical-temperate cladocerans Alona diaphana King, 1853 and Alona davidi Richard, 1895 and their translocation to Leberis Smirnov, 1989 (Branchiopoda: Anomopoda: Chydoridae). Arthropoda Selecta 14:183-205.

Sousa FD, Elmoor-Loureiro LM, Debastiani-Junior JR, Mugnai R, Senna A, 2015. New records of Anthalona acuta Van Damme, Sinev \& Dumont 2011 and Anthalona brandorffi (Sinev \& Hollwedel, 2002) in Brazil, with description of a new species of the simplex-branch (Crustacea: Cladocera: Chydoridae). Zootaxa 4044:224-240.

Szeroczyńska K, Sarmaja-Korjonen K, 2007. Atlas of Subfossil Cladocera from Central and Northern Europe. Friends of the Lower Vistula Society: 84 pp.

Van Damme K, Dumont HJ, 2007. Limb morphology of the carnivorous anomopods Anchistropus emarginatus Sars, 1862 and Pseudochydorus globosus (Baird, 1843) (Crustacea: Branchiopoda: Anomopoda). Ann. Limnol-Int. J. Lim. 43:271-284.

Wetzel A, 2013. Formation of methane-related authigenic carbonates within the bioturbated zone - An example from the upwelling area off Vietnam. Palaeogeogr. Palaeoclimatol. Palaeoecol. 386:23-33.

Zawiska I, Słowiński M, Correa-Metrio A, Obremska M, Luoto T, Nevalainen L, Woszczyk M, Milecka K, 2015. The response of a shallow lake and its catchment to Late Glacial climate changes - A case study from eastern Poland. Catena 126:1-10.

Zawiska I, Zawisza E, Woszczyk M, Szeroczyńska K, Spychalski W, Correa-Metrio A,2013. Cladocera and geochemical evidence from sediment cores show trophic changes in Polish dystrophic lakes. Hydrobiologia 715:181-193. 